\title{
Isotopic constraints on the atmospheric sources and formation of nitrogenous species in clouds influenced by biomass burning
}

\author{
Yunhua Chang ${ }^{1,2}$, Yan-Lin Zhang ${ }^{1}$, Jiarong Li $^{2}$, Chongguo Tian ${ }^{3}$, Linlin Song ${ }^{4}$, Xiaoyao Zhai ${ }^{1}$, Wenqi Zhang ${ }^{1}$, \\ Tong Huang ${ }^{1}$, Yu-Chi Lin ${ }^{1}$, Chao Zhu ${ }^{2}$, Yunting Fang ${ }^{4}$, Moritz F. Lehmann ${ }^{5}$, and Jianmin Chen ${ }^{2}$ \\ ${ }^{1}$ KLME \& CIC-FEMD, Yale-NUIST Center on Atmospheric Environment, \\ Nanjing University of Information Science \& Technology, Nanjing 210044, China \\ ${ }^{2}$ Shanghai Key Laboratory of Atmospheric Particle Pollution and Prevention $\left(\mathrm{LAP}^{3}\right)$, \\ Department of Environmental Science \& Engineering, Institute of Atmospheric Sciences, Fudan University, \\ Shanghai 200433, China \\ ${ }^{3}$ Key Laboratory of Coastal Environmental Processes and Ecological Remediation, Yantai Institute of Coastal Zone Research, \\ Chinese Academy of Sciences, Yantai 264003, China \\ ${ }^{4}$ CAS Key Laboratory of Forest Ecology and Management, Institute of Applied Ecology, Chinese Academy of Sciences, \\ Shenyang 110016, China \\ ${ }^{5}$ Aquatic and Isotope Biogeochemistry, Department of Environmental Sciences, University of Basel, Basel 4056, Switzerland
}

Correspondence: Yan-Lin Zhang (dryanlinzhang@ outlook.com) and Jianmin Chen (jmchen@fudan.edu.cn)

Received: 14 November 2018 - Discussion started: 10 December 2018

Revised: 2 August 2019 - Accepted: 14 August 2019 - Published: 2 October 2019

\begin{abstract}
Predicting tropospheric cloud formation and subsequent nutrient deposition relies on understanding the sources and processes affecting aerosol constituents of the atmosphere that are preserved in cloud water. However, this challenge is difficult to address quantitatively based on the sole use of bulk chemical properties. Nitrogenous aerosols, mainly ammonium $\left(\mathrm{NH}_{4}^{+}\right)$and nitrate $\left(\mathrm{NO}_{3}^{-}\right)$, play a particularly important role in tropospheric cloud formation. While dry and wet (mainly rainfall) deposition of $\mathrm{NH}_{4}^{+}$and $\mathrm{NO}_{3}^{-}$are regularly assessed, cloud water deposition is often underappreciated. Here we collected cloud water samples at the summit of Mt. Tai $(1545 \mathrm{~m}$ above sea level) in eastern China during a long-lasting biomass burning (BB) event and simultaneously measured for the first time the isotopic compositions (mean $\pm 1 \sigma)$ of cloud water nitrogen species $\left(\delta^{15} \mathrm{~N}-\mathrm{NH}_{4}^{+}=\right.$ $-6.53 \% \circ \pm 4.96 \%$ o, $\quad \delta^{15} \mathrm{~N}-\mathrm{NO}_{3}^{-}=-2.35 \% \circ \pm 2.00 \%$, $\delta^{18} \mathrm{O}-\mathrm{NO}_{3}^{-}=57.80 \% \circ \pm 4.23 \%$ ), allowing insights into their sources and potential transformation mechanism within the clouds. Large contributions of $\mathrm{BB}$ to the cloud water $\mathrm{NH}_{4}^{+}(32.9 \% \pm 4.6 \%)$ and $\mathrm{NO}_{3}^{-}(28.2 \% \pm 2.7 \%)$ inventories were confirmed through a Bayesian isotopic mixing model, coupled with our newly developed computational
\end{abstract}

quantum chemistry module. Despite an overall reduction in total anthropogenic $\mathrm{NO}_{x}$ emission due to effective emission control actions and stricter emission standards for vehicles, the observed cloud $\delta^{15} \mathrm{~N}-\mathrm{NO}_{3}^{-}$values suggest that $\mathrm{NO}_{x}$ emissions from transportation may have exceeded emissions from coal combustion. $\delta^{18} \mathrm{O}-\mathrm{NO}_{3}^{-}$values imply that the reaction of $\mathrm{OH}$ with $\mathrm{NO}_{2}$ is the dominant pathway of $\mathrm{NO}_{3}^{-}$ formation $(57 \% \pm 11 \%)$, yet the contribution of heterogeneous hydrolysis of dinitrogen pentoxide was almost as important $(43 \% \pm 11 \%)$. Although the limited sample set used here results in a relatively large uncertainty with regards to the origin of cloud-associated nitrogen deposition, the high concentrations of inorganic nitrogen imply that clouds represent an important source of nitrogen, especially for nitrogen-limited ecosystems in remote areas. Further simultaneous and long-term sampling of aerosol, rainfall, and cloud water is vital for understanding the anthropogenic influence on nitrogen deposition in the study region. 


\section{Introduction}

Nitrogenous aerosols, mainly nitrate $\left(\mathrm{NO}_{3}^{-}\right)$and ammonium $\left(\mathrm{NH}_{4}^{+}\right)$, formed from the emissions of nitrogen oxides $\left(\mathrm{NO}_{x}\right.$ $\left.=\mathrm{NO}+\mathrm{NO}_{2}\right)$ and ammonia $\left(\mathrm{NH}_{3}\right)$ and are major chemical components of aerosols, which serve as cloud condensation nuclei $(\mathrm{CCN})$ and thus play an important role during cloud formation in the troposphere (Gioda et al., 2011; van Pinxteren et al., 2016). Cloud water nitrogenous compounds also represent a vital contributor to nitrogen $(\mathrm{N})$ budgets of terrestrial (Li et al., 2016b; Liu et al., 2013; Weathers and Likens, 1997; Vega et al., 2019) and marine ecosystems (Kim et al., 2014; Okin et al., 2011). However, the sources and formation processes of cloud water $\mathrm{N}$ species are only poorly understood.

$\mathrm{NO}_{x}$ can be emitted from both anthropogenic and natural sources. Globally, over $50 \%$ of the $\mathrm{NO}_{x}$ emissions derive from combustion of fossil fuels $\left(\sim 25 \mathrm{Tg} \mathrm{N} \mathrm{yr}^{-1}\right.$; Jaegle et al., 2005; Richter et al., 2005; Duncan et al., 2016) with the remainder being primarily soil-related emissions ( $\sim 9 \mathrm{Tg} \mathrm{Nyr}^{-1}$; Lamsal et al., 2011; Price et al., 1997; Yienger and Levy, 1995; Miyazaki et al., 2017) or deriving from biomass burning $\left(\sim 6 \mathrm{Tg} \mathrm{Nyr}^{-1}\right)$ and lightning $(2-$ $6 \mathrm{Tg} \mathrm{N} \mathrm{yr}^{-1}$ ) (Anenberg et al., 2017; Levy et al., 1996). The atmospheric sinks of $\mathrm{NO}_{x}$ include the production of $\mathrm{HNO}_{3}(\mathrm{~g})$ and the formation of aerosol $\mathrm{NO}_{3}^{-}$(Seinfeld and Pandis, 2012), the partitioning of which can vary with time (Morino et al., 2006). As for $\mathrm{NH}_{3}$, over $90 \%$ of the $\mathrm{NH}_{3}$ emissions in terrestrial ecosystems originate from agricultural production, such as livestock breeding and $\mathrm{NH}_{3}$-based fertilizer application (Paulot and Jacobs, 2014; Kang et al., 2016; Reis et al., 2009; Bouwman et al., 1997; Heald et al., 2012; Zhang et al., 2018; Balasubramanian et al., 2015; Huang et al., 2011). In the urban atmosphere, recent studies suggest that nonagricultural activities like wastewater discharge (Zhang et al., 2017), coal burning (Li et al., 2016a), solid waste (Reche et al., 2012), on-road traffic (Suarez-Bertoa et al., 2014), and green spaces (Teng et al., 2017) also contribute to $\mathrm{NH}_{3}$ emissions. In reactions with $\mathrm{H}_{2} \mathrm{SO}_{4}$ and $\mathrm{HNO}_{3}, \mathrm{NH}_{3}$ contributes to the formation of $\mathrm{NH}_{4}^{+}$salts, which typically make up from $20 \%$ to $80 \%$ of fine particles $\left(\mathrm{PM}_{2.5}\right)$ in the atmosphere (Seinfeld and Pandis, 2012).

Biomass burning (BB) is an important source of $\mathrm{N}$ in the atmosphere (Lobert et al., 1990; Souri et al., 2017). During the harvest or hot season of eastern China, agricultural BB frequently occurs and modifies the concentration and composition of aerosols in the atmosphere (Chen et al., 2017; Zhang and Cao, 2015). For example, about $50 \%$ of the $\mathrm{N}$ derived from biomass combustion can be released as $\mathrm{NH}_{3}$ and $\mathrm{NO}_{x}$ to form particulate $\mathrm{NH}_{4}^{+}$and $\mathrm{NO}_{3}^{-}$, which then account for over $80 \%$ of total nitrogenous species in BB smoke particles (Crutzen and Andreae, 1990). BB-induced aerosols have not only been associated with poor air quality and the detrimental effects on human health but have also shown to exert manifold effects on tropospheric clouds, altering regional or even global radiation budgets (Chen et al., 2014; Norris et al., 2016; Voigt and Shaw, 2015).

The optical and chemical properties of clouds (and thus their radiative forcing) are directly related to the aerosol and precipitation chemistry (Seinfeld et al., 2016). Moreover, clouds represent reactors of multiphase chemistry, contributing to many chemical transformations that would otherwise not take place or would proceed at much slower rates (Herrmann et al., 2015; Lance et al., 2017; Ravishankara, 1997; Schurman et al., 2018; Slade et al., 2017). Understanding the sources and fate of nitrogenous species in BB-influenced clouds is particularly important to comprehensively assess the environmental impacts of BB. But this challenge is difficult to address based on the sole use of bulk chemical properties (as most often done in previous studies).

Given that ${ }^{15} \mathrm{~N}$ can be preserved between the sources and sinks of $\mathrm{NO}_{x}$ and $\mathrm{NH}_{3}$, the $\mathrm{N}$ isotopic composition of $\mathrm{NO}_{3}^{-}$ $\left(\delta^{15} \mathrm{~N}_{-} \mathrm{NO}_{3}^{-}\right)$and $\mathrm{NH}_{4}^{+}\left(\delta^{15} \mathrm{~N}^{-\mathrm{NH}_{4}^{+}}\right)$can be related to different sources of $\mathrm{NO}_{x}$ and $\mathrm{NH}_{3}$, and thus delivers useful information regarding the partitioning of the origins of atmospheric cloud water $\mathrm{NO}_{x}$ and $\mathrm{NH}_{3}$, respectively (Hastings et al., 2013; Michalski et al., 2005; Morin et al., 2008; Chang et al., 2018). This is different for the $\mathrm{O}$ isotopes. $\mathrm{NO}_{3}^{-}$ production involves the oxidation of NO. The first step in the overall process is the conversion of $\mathrm{NO}$ into $\mathrm{NO}_{2}$, e.g., through the oxidation by either ozone $\left(\mathrm{O}_{3}\right)$ or peroxy radicals (Michalski et al., 2011). Significant ${ }^{18} \mathrm{O}$ enrichments and excess ${ }^{17} \mathrm{O}$ (i.e., clear evidence for mass-independent fractionation) are observed in atmospheric $\mathrm{NO}_{3}^{-}$collected across the globe (e.g., Michalski et al., 2005; Hastings et al., 2003). Such diagnostic isotope signatures, as well as their variability in space and time, have been linked to the extent of $\mathrm{O}_{3}$ oxidation (Michalski et al., 2011). Put another way, the oxygen

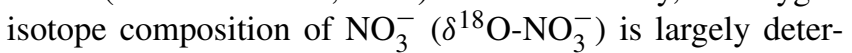
mined by chemical reactions rather than the source, and it is primarily modulated by the $\mathrm{O}$-atom exchange (Michalski et al., 2011) in the atmosphere. Therefore, $\delta^{18} \mathrm{O}-\mathrm{NO}_{3}^{-}$has the potential to indicate the relative importance of various $\mathrm{NO}_{3}^{-}$ formation pathways (i.e., oxidation pathways during conversion of nitrogen oxides to $\mathrm{NO}_{3}$ ) (Alexander et al., 2009; Elliott et al., 2009).

The $\mathrm{O}$ isotope fractionation during the conversion of $\mathrm{NO}_{x}$ to $\mathrm{HNO}_{3} / \mathrm{NO}_{3}^{-}\left(\varepsilon_{\mathrm{O}_{\left(\mathrm{NO}_{x} \leftrightarrow \mathrm{HNO}_{3}\right)}} / \varepsilon_{\left.\mathrm{O}_{\left(\mathrm{NO}_{x} \leftrightarrow \mathrm{NO}_{3}^{-}\right.}\right)}\right)$involves two oxidation pathways (Hastings et al., 2003)

$$
\begin{aligned}
& \varepsilon_{\mathrm{O}_{\left(\mathrm{NO}_{x} \leftrightarrow \mathrm{NO}_{3}^{-}\right)}}=\varepsilon_{\mathrm{O}_{\left(\mathrm{NO}_{x} \leftrightarrow \mathrm{HNO}_{3}\right)}}=\gamma \times \varepsilon_{\mathrm{O}_{\left(\mathrm{NO}_{x} \leftrightarrow \mathrm{NO}_{3}^{-}\right)_{\mathrm{OH}}}}
\end{aligned}
$$

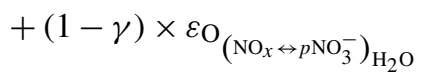

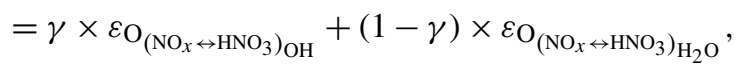

where $\gamma /(1-\gamma)$ represents the contribution ratio of the isotope fractionation associated with the formation of $\mathrm{HNO}_{3} / \mathrm{NO}_{3}^{-}$through the " $\mathrm{OH}+\mathrm{NO}_{2}$ " pathway $\left.\left(\varepsilon_{\mathrm{O}_{(}} \mathrm{NO}_{x} \leftrightarrow \mathrm{NO}_{3}^{-}\right)_{\mathrm{OH}}\right)$ and the hydrolysis of dinitrogen pen- 


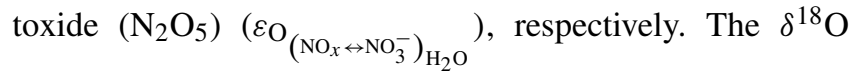
value of $\mathrm{HNO}_{3}$ produced by the former process reflects the $\mathrm{O}$ atom partitioning of two-thirds $\mathrm{O}_{3}$ and one-third $\mathrm{OH}$ (Chang et al., 2018):

$$
\begin{aligned}
& \varepsilon_{\mathrm{O}_{\left(\mathrm{NO}_{x} \leftrightarrow \mathrm{NO}_{3}^{-}\right)_{\mathrm{OH}}}}=\varepsilon_{\mathrm{O}_{\left(\mathrm{NO}_{x} \leftrightarrow \mathrm{HNO}_{3}\right)_{\mathrm{OH}}}}=\frac{2}{3} \varepsilon_{\mathrm{O}_{\left(\mathrm{NO}_{2} \leftrightarrow \mathrm{HNO}_{3}\right)_{\mathrm{OH}}}} \\
& +\frac{1}{3} \varepsilon_{\mathrm{O}_{\left(\mathrm{NO} \leftrightarrow \mathrm{HNO}_{3}\right)_{\mathrm{OH}}}} \\
& =\frac{2}{3}\left[\frac{1000\left({ }^{18} \alpha_{\mathrm{NO}_{2} / \mathrm{NO}}-1\right)\left(1-\mathrm{f}_{\mathrm{NO}_{2}}\right)}{\left(1-\mathrm{f}_{\mathrm{NO}_{2}}\right)+\left({ }^{18} \alpha_{\mathrm{NO}_{2} / \mathrm{NO}} \times f_{\mathrm{NO}_{2}}\right)}+\left(\delta^{18} \mathrm{O}-\mathrm{NO}_{x}\right)\right] \\
& +\frac{1}{3}\left[\left(\delta^{18} \mathrm{O}-\mathrm{H}_{2} \mathrm{O}\right)+1000\left({ }^{18} \alpha_{\mathrm{OH} / \mathrm{H}_{2} \mathrm{O}}-1\right)\right] \text {. }
\end{aligned}
$$

As for the $\delta^{18} \mathrm{O}$ value of $\mathrm{HNO}_{3}$ formed during hydrolysis of $\mathrm{N}_{2} \mathrm{O}_{5}$, five-sixths of the $\mathrm{O}$ atoms are derived from $\mathrm{O}_{3}$ and one-sixth from $\mathrm{OH}$ (Hastings et al., 2003):

$$
\begin{aligned}
& \varepsilon_{\mathrm{O}_{\left(\mathrm{NO}_{x} \leftrightarrow \mathrm{NO}_{3}^{-}\right)_{\mathrm{H}_{2} \mathrm{O}}}}=\varepsilon_{\mathrm{O}_{\left(\mathrm{NO}_{x} \leftrightarrow \mathrm{HNO}_{3}\right)_{\mathrm{H}_{2} \mathrm{O}}}}=\frac{5}{6}\left(\delta^{18} \mathrm{O}-\mathrm{N}_{2} \mathrm{O}_{5}\right) \\
& +\frac{1}{6}\left(\delta^{18} \mathrm{O}-\mathrm{H}_{2} \mathrm{O}\right),
\end{aligned}
$$

where $f_{\mathrm{NO}_{2}}$ refers to the fraction of $\mathrm{NO}_{2}$ in the total $\mathrm{NO}_{x}$ pool. Values for $f_{\mathrm{NO}_{2}}$ vary between 0.2 and 0.95 (Walters and Michalski, 2015). $\delta^{18} \mathrm{O}-X$ is the $\mathrm{O}$ isotopic composition of $X$. The range of $\delta^{18} \mathrm{O}-\mathrm{H}_{2} \mathrm{O}$ can be approximated using an estimated tropospheric water vapor $\delta^{18} \mathrm{O}$ range of $-25 \%$ to $0 \%$ (Zong et al., 2017). The $\delta^{18} \mathrm{O}$ of $\mathrm{NO}_{2}$ and $\mathrm{N}_{2} \mathrm{O}_{5}$ varies between $90 \%$ and $122 \%$ (Zong et al., 2017). ${ }^{18} \alpha_{\mathrm{NO}_{2} / \mathrm{NO}}$ and ${ }^{18} \alpha_{\mathrm{OH} / \mathrm{H}_{2} \mathrm{O}}$ represent the equilibrium $\mathrm{O}$ isotope fractionation factors between $\mathrm{NO}_{2}$ and $\mathrm{NO}$ and $\mathrm{OH}$ and $\mathrm{H}_{2} \mathrm{O}$, respectively, which is temperature dependent:

$$
\begin{aligned}
& 1000\left({ }^{\mathrm{m}} \alpha_{X / Y}-1\right)=\frac{\mathrm{A}}{T^{4}} \times 10^{10}+\frac{\mathrm{B}}{T^{3}} \times 10^{8}+\frac{\mathrm{C}}{T^{2}} \\
& \times 10^{6}+\frac{\mathrm{D}}{T} \times 10^{4},
\end{aligned}
$$

where $\mathrm{A}, \mathrm{B}, \mathrm{C}$, and $\mathrm{D}$ are experimental constants over the temperature range of 150-450 K. Based on Eqs. (1)-(4) and measured values for $\delta^{18} \mathrm{O}-\mathrm{NO}_{3}^{-}$of cloud water, a Monte Carlo simulation was performed to generate 10000 feasible solutions. The error between predicted and measured $\delta^{18} \mathrm{O}$ was less than $0.5 \%$.

At the end of July 2015, a large-scale BB event occurred over eastern and northern China. We took advantage of this special event to collect cloud water samples at a high-altitude mountaintop site in the North China Plain and to calibrate the isotopic signatures that $\mathrm{BB}$ events leave in the $\mathrm{N}$ pool of clouds. Integrating cloud water nitrogenous-species isotopic data $\left(\delta^{15} \mathrm{~N}-\mathrm{NH}_{4}^{+}, \delta^{15} \mathrm{~N}-\mathrm{NO}_{3}^{-}\right.$, and $\left.\delta^{18} \mathrm{O}-\mathrm{NO}_{3}^{-}\right)$into a Bayesian isotopic mixing model coupled with a newly developed computational quantum chemistry module (Chang et al., 2018), and using an isotopic mass balance approach, the sources and production pathways of inorganic nitrogen in cloud water were quantified. Although numerous studies have been conducted that involved the chemical characterization of fog water or cloud water, to our knowledge there are no reports on the $\mathrm{N}$ (and $\mathrm{O}$ ) isotopic composition of both $\mathrm{NO}_{3}^{-}$and $\mathrm{NH}_{4}^{+}$in cloud water.

\section{Materials and methods}

\subsection{Cloud water sample collection}

Mt. Tai $\left(36^{\circ} 18^{\prime} \mathrm{N}, 117^{\circ} 13^{\prime} \mathrm{E} ; 1545 \mathrm{~m}\right.$ above sea level) is a world-recognized geopark of key natural, historical, and cultural significance, located in the eastern North China Plain (Fig. 1). It belongs to China's most important agricultural and industrial production areas, and the composition of the atmosphere near the mountain can be considered representative with regards to the quality and levels of atmospheric pollution in the region (Li et al., 2017; Liu et al., 2018). Given the opportunistic nature of this study, cloud water sampling commenced at the summit of Mt. Tai $3 \mathrm{~d}$ after the fire began (8 January 2015 19:12 LT (local time) to 8 March 2015 06:12 LT; Table 1). In total, six cloud water samples were collected during the long-lasting cloud event using a singlestage Caltech active strand cloud water collector (CASCC), as described by (Demoz et al., 1996). The cloud collector was cleaned prior to each sampling using high-purity deionized water. After sampling, cloud samples were filtered immediately using disposable syringe filters $(0.45 \mu \mathrm{m})$ to remove any suspended particulate matter and then stored in a freezer at $-80^{\circ} \mathrm{C}$ until further analysis. More details on the monitoring site and sampling procedures can be found elsewhere ( $\mathrm{Li}$ et al., 2017).

\subsection{Chemical and isotopic analysis}

Inorganic ions (including $\mathrm{SO}_{4}^{2-}, \mathrm{NO}_{3}^{-}, \mathrm{Cl}^{-}, \mathrm{NH}_{4}^{+}, \mathrm{K}^{+}, \mathrm{Ca}^{2+}$, $\mathrm{Mg}^{2+}$, and $\mathrm{Na}^{+}$), as well as levoglucosan (a specific tracer of biomass burning), in cloud water samples were analyzed using a Dionex ${ }^{\mathrm{TM}}$ ICS $-5000^{+}$system (Thermo Fisher Scientific, Sunnyvale, USA). The IC (ion chromatograph) system was equipped with an automated sampler (AS-DV). Cloud water samples were measured using an IonPac CG12A guard column and a CS12A separation column with an aqueous methanesulfonic acid (MSA, $30 \mathrm{mML}^{-1}$ ) eluent at a flow rate of $1 \mathrm{~mL} \mathrm{~min}^{-1}$. Detailed information regarding sample processing, pretreatment, chemical analyses, and analytical protocol adaption can be found elsewhere (Cao et al., 2016, 2017). The detection limits for $\mathrm{Na}^{+}, \mathrm{NH}_{4}^{+}, \mathrm{K}^{+}, \mathrm{Mg}^{2+}, \mathrm{Ca}^{2+}$, $\mathrm{Cl}^{-}, \mathrm{NO}_{2}^{-}, \mathrm{NO}_{3}^{-}, \mathrm{SO}_{4}^{2-}$, and levoglucosan are 0.06, 0.03, $0.12,0.08,0.13,0.64,1.11,2.67,1.41$, and $1.29 \mathrm{ppb}$ (parts per billion by weight in solution), respectively. The analytical errors from duplicate analyses were within $5 \%$. 


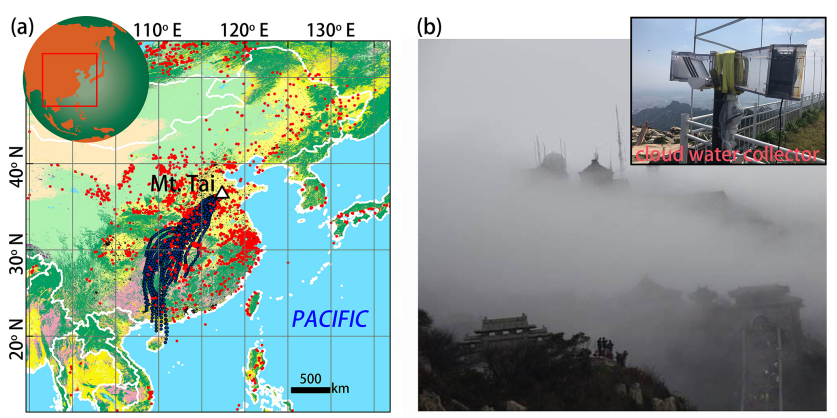

Figure 1. (a) Location of Mt. Tai (triangle) and twenty-four $48 \mathrm{~h}$ back trajectories (black lines) of air masses simulated by the HYSPLIT model (http://ready.arl.noaa.gov/HYSPLIT.php, last access: 10 August 2019) based on the Global Data Assimilation System (GDAS) meteorological data set arriving at Mt. Tai on $1 \mathrm{Au}-$ gust 2015 (04:00 UTC) at an altitude $1500 \mathrm{~m}$ a.s.l (close to the altitude of our sampling site). The base map of land use in China was modified from Chang et al. (2018). The red dots represent the positions of wildfires between 29 and 31 July 2015, based on the Moderate Resolution Imaging Spectroradiometer (MODIS) (http://modis-fire.umd.edu, last access: 10 August 2019). (b) Field photos of cloud-shrouded Mt. Tai and the cloud water collector.

Analysis of the isotopic compositions of $\mathrm{NH}_{4}^{+}$ $\left(\delta^{15} \mathrm{~N}^{-\mathrm{NH}_{4}^{+}}\right)$and $\mathrm{NO}_{3}^{-} \quad\left(\delta^{15} \mathrm{~N}^{-\mathrm{NO}_{3}^{-}}\right.$and $\left.\delta^{18} \mathrm{O}-\mathrm{NO}_{3}^{-}\right)$ was based on the isotopic analysis of nitrous oxides $\left(\mathrm{N}_{2} \mathrm{O}\right)$ after chemical conversion of the respective target compound. More precisely, dissolved $\mathrm{NH}_{4}^{+}$in cloud water samples was oxidized to $\mathrm{NO}_{2}^{-}$by alkaline hypobromite $\left(\mathrm{BrO}^{-}\right)$ and then reduced to $\mathrm{N}_{2} \mathrm{O}$ by hydroxylamine hydrochloride $\left(\mathrm{NH}_{2} \mathrm{OH} \cdot \mathrm{HCl}\right)$ (Liu et al., 2014). $\mathrm{NO}_{3}^{-}$was initially transformed to $\mathrm{NO}_{2}^{-}$by cadmium and then further reduced to $\mathrm{N}_{2} \mathrm{O}$ by sodium azide $\left(\mathrm{NaN}_{3}\right)$ in an acetic acid buffer (McIlvin and Altabet, 2005; Tu et al., 2016). The produced $\mathrm{N}_{2} \mathrm{O}$ was analyzed using a purge and cryogenic trap system (Gilson GX-271, Isoprime Ltd., Cheadle Hulme, UK), coupled to an isotope ratio mass spectrometer (PT-IRMS) (Isoprime 100, Isoprime Ltd., Cheadle Hulme, UK). In order to correct for any machine drift and procedural blank contribution, international $\mathrm{NH}_{4}^{+}$(IAEA N1, USGS 25, and USGS 26) and $\mathrm{NO}_{3}^{-}$(IAEA N3, USGS 32, and USGS 34) standards were processed in the same way as samples. Standard regressions were made based on the known isotopic values of international standards and the measured standard $\delta^{15} \mathrm{~N}$ values. For the $\mathrm{NO}_{3}^{-}$derived $\mathrm{NO}_{2}^{-}$analysis, the slope of the plot of the sample versus the standard $\delta^{15} \mathrm{~N}(0.49)$ was very close to the expected slope $(0.5)$, which can be predicted based on the fact that half of the $\mathrm{N}$ atoms were derived from the azide (McIlvin and Altabet, 2005). The $r^{2}$ of the regression line was 0.999 . The analytical precision for both multiple $\mathrm{N}$ and $\mathrm{O}$ isotopic analyses was better than $0.3 \%$ o $(n=5)$.

\subsection{Bayesian mixing model analysis}

By taking the uncertainty associated with the $\mathrm{N}$ isotopic signatures of multiple sources and associated isotope fractionation during (trans-)formations into account, the Bayesian method is more appropriate than simple linear mixing modeling to yield estimates on the source partitioning of a mixture like air pollutants (Chang et al., 2016, 2018). The relative contribution of each source in the Bayesian theorem is expressed as

$$
\begin{aligned}
& P\left(f_{\mathrm{q}} \mid \text { data }\right)=\theta\left(\text { data } \mid f_{\mathrm{q}}\right) \times P\left(f_{\mathrm{q}}\right) / \sum \theta\left(\text { data } \mid f_{\mathrm{q}}\right) \\
& \times P\left(f_{\mathrm{q}}\right),
\end{aligned}
$$

where $\theta$ (data| $f_{\mathrm{q}}$ ) and $\mathrm{P}\left(f_{\mathrm{q}}\right)$ represent the likelihood of the given mixed isotope signature and the predetermined probability of the given state of nature, based on prior information, respectively. The denominator represents the numerical approximation of the marginal probability of the data. Here the Bayesian mixing model MixSIR (stable isotope mixing models using the sampling-importance-resampling method) was used to disentangle the various potential $\mathrm{NH}_{3}$ and $\mathrm{NO}_{x}$ sources contributing to the cloud water $\mathrm{NH}_{4}^{+}$and $\mathrm{NO}_{3}^{-}$pools, respectively, by forming the true probability distributions through generating 10000 solutions of source apportionment. Details on the model approach can be found in Appendix A.

The measured $\delta^{15} \mathrm{~N}-\mathrm{NO}_{3}^{-}$values of cloud water samples depend on the $\delta^{15} \mathrm{~N}$ signatures of the original $\mathrm{NO}_{x}$ sources $\left(\delta^{15} \mathrm{~N}-\mathrm{NO}_{x}\right)$, the $\mathrm{N}$ isotope fractionation between nitrogen oxides (i.e., $\mathrm{NO}$ and $\mathrm{NO}_{2}$; Walters et al., 2016), and the $\mathrm{N}$ isotope enrichment factor $\left(\varepsilon_{\mathrm{N}}\right)$ associated with the kinetic transformation of $\mathrm{NO}_{x}$ to $\mathrm{HNO}_{3}$ (Walters and Michalski, 2015). $\varepsilon_{\mathrm{N}}$ is considered a hybrid of two dominant processes: one is the reaction of $\mathrm{NO}_{2}$ and $\mathrm{OH}$ radicals to form $\mathrm{NO}_{3}^{-}$and the other is the heterogeneous hydrolysis of dinitrogen pentoxide $\left(\mathrm{N}_{2} \mathrm{O}_{5}\right)$ with water to form $\mathrm{NO}_{3}^{-}$. We recently developed a quantum chemistry computation module to quantify the $\mathrm{N}$ fractionation during nitrate formation, which had been validated by field measurements (Chang et al., 2018). Here this module was adopted to calculate the $\mathrm{N}$ isotope fractionation during $\mathrm{NO}_{3}^{-}$formation, and in turn to correct the raw

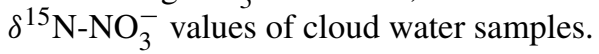

While the $\mathrm{N}$ isotopic source signatures of $\mathrm{NO}_{x}$ are relatively well constrained (Table B1 in Appendix B), this is not the case for $\mathrm{NH}_{3}$. We recently established a pool of isotopic source signatures of $\mathrm{NH}_{3}$ in eastern China, from which livestock breeding and fertilizer application were identified to produce $\mathrm{NH}_{3}$ with a $\delta^{15} \mathrm{~N}$ of $-29.1 \% \circ \pm 1.7 \%$ o and $-50.0 \% \circ \pm 1.8 \%$, respectively (Chang et al., 2016). Although fossil fuel combustion, urban waste, and natural soils also represent potential sources of $\mathrm{NH}_{3}$, their impacts are probably minor compared to those of agricultural and biomass burning emissions, at least on a regional (or greater) scale (Kang et al., 2016). For the $\mathrm{N}$ isotope sig- 
nature of biomass-burning-derived $\mathrm{NH}_{3}$, we assumed $12 \%$ o (Kawashima and Kurahashi, 2011), a value that has also been applied in other recent isotope-based source apportionment studies (e.g., Chellman et al., 2016; Wang et al., 2017a).

\section{Results and discussion}

\subsection{Chemical characterization of biomass-burning-influenced clouds}

The Moderate Resolution Imaging Spectroradiometer (MODIS) wildfire map (Fig. 1) shows that there were intensive biomass burning events occurring over mainland China, end of July 2015, just before the study period. Moreover, analysis of the back trajectories of air masses at the study site revealed the strong influence of atmospheric transport from regions that also experienced intensive biomass burning events shortly before the sampling campaign. It can thus be assumed that large amounts of BB-related pollutants were transported from the southwest to the sampling site at Mt. Tai. Table 1 compiles sample information and results from the chemical and isotopic analysis of cloud water samples in this study. The concentrations of $\mathrm{NO}_{3}^{-}$and $\mathrm{NH}_{4}^{+}$ ranged from 4.9 to $19.9 \mathrm{mg} \mathrm{L}^{-1}$ (10.1 $\mathrm{mg} \mathrm{L}^{-1}$ on average) and from 4.9 to $18.0 \mathrm{mg} \mathrm{L}^{-1}$ (9.1 $\mathrm{mg} \mathrm{L}^{-1}$ on average), respectively, much higher than during non-BB seasons (Chen et al., 2017; Desyaterik et al., 2013; Li et al., 2017, 2018; Lin et al., 2017). Similarly, levoglucosan in our cloud water samples varied between 12.1 and $35.1 \mu \mathrm{g} \mathrm{L}^{-1}$ (19.9 $\mu \mathrm{g} \mathrm{L}^{-1}$ on average), and concentrations were thus 1 order of magnitude higher than those documented during non-BB seasons (Boone et al., 2015; Fomba et al., 2015). Although levoglucosan can be oxidized by $\mathrm{OH}$ radicals in the tropospheric aqueous phase (Sang et al., 2016), it is nevertheless a reliable marker compound for BB due to its high-emission factors and relatively high concentrations in the ambient aerosols (Hoffmann et al., 2010). In our study, the concentrations of $\mathrm{NO}_{3}^{-}\left(r^{2}=0.55\right)$ and $\mathrm{NH}_{4}^{+}$ $\left(r^{2}=0.66\right)$ are strongly correlated with that of levoglucosan, suggesting that the pronounced increase in $\mathrm{NO}_{3}^{-}$and $\mathrm{NH}_{4}^{+}$ levels observed here can at least be partly attributed to $\mathrm{BB}$ activities during the study period. Globally, BB accounts for around $10 \%$ of $\mathrm{NH}_{3}$ and $\mathrm{NO}_{x}$ emissions (Benkovitz et al., 1996; Bouwman et al., 1997; Olivier et al., 1998; Schlesinger and Hartley, 1992).

\subsection{Isotopic characterization of biomass-burning-influenced clouds}

The $\mathrm{N}$ (and $\mathrm{O}$ ) isotopic composition of cloud water nitrogenous species was more $\left(\mathrm{NH}_{4}^{+}\right)$or less $\left(\mathrm{NO}_{3}^{-}\right)$variable (Table 1), with the average $\delta^{15} \mathrm{~N}$ values of $6.53 \%$ and $-2.35 \%$ o for $\mathrm{NH}_{4}^{+}$and $\mathrm{NO}_{3}^{-}$, respectively. The average $\delta^{18} \mathrm{O}-\mathrm{NO}_{3}^{-}$ value was $57.80 \%$. These values are generally different from gas, rainwater, and aerosol values measured worldwide
(Fig. 2). Various atmospheric processes can influence the isotopic composition of atmospheric nitrogenous species including the original emission source of $\mathrm{NO}_{x}$, seasonality of oxidation pathways, isotope fractionation during transport, partitioning between wet and dry components, and spatial gradients in atmospheric chemistry (Elliott et al., 2007; Hastings et al., 2003). These aspects may affect the $\delta^{15} \mathrm{~N}$ and $\delta^{18} \mathrm{O}$ values differentially. For example, the $\delta^{15} \mathrm{~N}$ of atmospheric $\mathrm{NO}_{3}^{-}$retains spatial changes in the original $\mathrm{NO}_{x}$ signature quite well, in contrast to the $\delta^{18} \mathrm{O}$. On the other hand, the $\delta^{18} \mathrm{O}$ most strongly depends on the oxidation chemistry and formation pathway in the atmosphere (see Eqs. 1-4).

At present, there are no other reports on the isotope ratios of both $\mathrm{NO}_{3}^{-}$and $\mathrm{NH}_{4}^{+}$in cloud water, and a comparison is possible only with isotopic data from precipitation and aerosol N. Recently, Vega et al. (2019) reported the $\delta^{15} \mathrm{~N}$ $\left(-8 \% \circ \pm 2 \%\right.$ ) and $\delta^{18} \mathrm{O}\left(71 \% \circ \pm 3 \%\right.$ ) values of $\mathrm{NO}_{3}^{-}$in fog water at a forest site in Sweden. The relatively high $\delta^{15} \mathrm{~N}$ values in our study $\left(-2.35 \%\right.$ o) suggest more $\mathrm{NO}_{x}$ was emitted from combustion processes. In contrast, the much higher $\delta^{18} \mathrm{O}$ values in Vega et al. (2019) indicate a much greater contribution from $\mathrm{O}_{3}$ in sub-Arctic environments. In Fig. 2a, $\mathrm{N}$ isotopic differences for $\mathrm{NO}_{x}$ sources are greater $(35 \%$ ) than for $\delta^{18} \mathrm{O}-\mathrm{NO}_{x}$. In fact, the oxygen isotope signature of $\mathrm{NO}_{x}$ is mainly driven by chemistry rather than determined by the source (see discussion below), and thus $\delta^{18} \mathrm{O}$ measurements cannot be used to address the uncertainty in the $\mathrm{NO}_{x}$ sources that may remain when just looking at $\delta^{15} \mathrm{~N}$ values alone. As shown in Fig. $2 \mathrm{~b}$, the $\delta^{15} \mathrm{~N}$ values of aerosol $\mathrm{NH}_{4}^{+}$are systematically higher than that of $\mathrm{NH}_{3}$. Significant $\varepsilon_{N}$ during the conversion of gas to aerosol (up to $33 \%$ ) has been proposed to alter the $\delta^{15} \mathrm{~N}$ values during the transformation of the source $\left(\mathrm{NH}_{3}\right)$ to the sink (particulate $\mathrm{NH}_{4}^{+}$). Indeed, our compilation of previous results (Fig. 2b) reveals that particulate $\mathrm{NH}_{4}^{+}$(particularly in the coarse aerosol fraction) is more enriched in ${ }^{15} \mathrm{~N}$ than $\mathrm{NH}_{3}$ (by $>23 \%$ on average), as well as $\mathrm{NH}_{4}^{+}$in precipitation (by $18 \%$ on average). This can most likely be attributed to the preferential absorption of ${ }^{14} \mathrm{~N}-\mathrm{NH}_{3}$ associated with washout processes during precipitation (Zheng et al., 2018). We are aware of the fact that our sample and data used here are limited, resulting in a relatively large uncertainty with regards to the $\mathrm{N}$ isotopebased source apportionment. However, all $\delta^{15} \mathrm{~N}_{-} \mathrm{NH}_{4}^{+}$values in cloud water samples fall within the observed range of

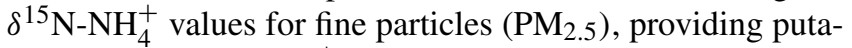
tive evidence that $\mathrm{NH}_{4}^{+}$in cloud water is primarily derived from particulate $\mathrm{NH}_{4}^{+}$rather than $\mathrm{NH}_{3}$ absorption.

\subsection{Isotope-based assessment of the sources and formation of nitrogenous species in clouds}

Using the MixSIR model, the relative contribution of four $\mathrm{NH}_{3}$ sources to $\mathrm{NH}_{4}^{+}$can be calculated, based on the isotope data of ambient $\delta^{15} \mathrm{~N}^{-\mathrm{NH}_{4}^{+}}$and considering the $\mathrm{N}$ fractionation and prior information on the site. As upper limit 
Table 1. Sampling details and results of chemical and isotopic analysis for collected cloud water samples.

\begin{tabular}{|c|c|c|c|c|c|c|c|}
\hline Date & Local time & $\begin{array}{r}\mathrm{NO}_{3}^{-} \\
\left(\mathrm{mg} \mathrm{L}^{-1}\right)\end{array}$ & $\begin{array}{r}\mathrm{NH}_{4}^{+} \\
\left(\mathrm{mg} \mathrm{L}^{-1}\right)\end{array}$ & $\begin{array}{r}\text { Levoglucosan } \\
\left(\mu \mathrm{g} \mathrm{L}^{-1}\right)\end{array}$ & $\begin{array}{r}\delta^{15} \mathrm{~N}-\mathrm{NO}_{3}^{-} \\
(\% \circ)\end{array}$ & $\begin{array}{r}\delta^{18} \mathrm{O}-\mathrm{NO}_{3}^{-} \\
(\% \circ)\end{array}$ & $\begin{array}{r}\delta^{15} \mathrm{~N}-\mathrm{NH}_{4}^{+} \\
(\% \circ)\end{array}$ \\
\hline \multirow{2}{*}{1 Aug } & $19: 12-22: 58$ & 19.86 & 17.99 & 35.06 & -0.22 & 65.46 & 3.62 \\
\hline & $23: 45-08: 25$ & 4.88 & 4.92 & 12.11 & -1.28 & 55.01 & 3.85 \\
\hline \multirow{4}{*}{$2 \mathrm{Aug}$} & 09:10-12:19 & 5.57 & 5.81 & 23.60 & -0.40 & 59.84 & 0.05 \\
\hline & $12: 55-18: 30$ & 13.24 & 11.51 & 18.67 & -4.18 & 55.66 & 11.34 \\
\hline & 20:02-23:06 & 10.06 & 7.74 & 13.63 & -3.11 & 56.63 & 12.99 \\
\hline & $23: 48-06: 12$ & 6.71 & 6.59 & 16.42 & -4.92 & 54.19 & 7.33 \\
\hline
\end{tabular}
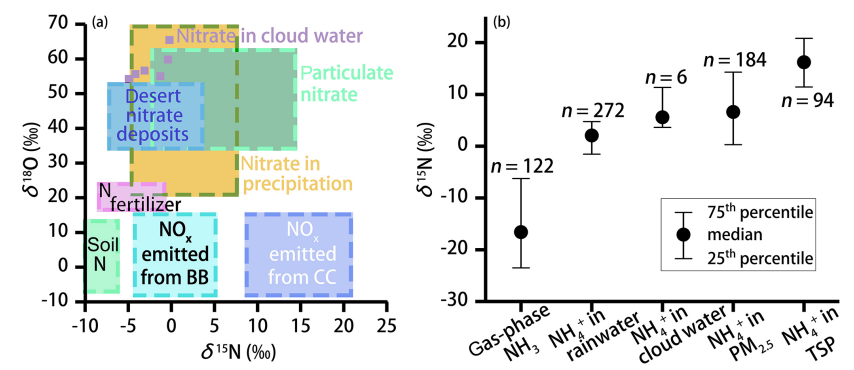

Figure 2. (a) Observed range of typical $\delta^{18} \mathrm{O}$ and $\delta^{15} \mathrm{~N}$ values of $\mathrm{NO}_{3}^{-}$and $\mathrm{NO}_{x}$ for different sources (adapted from Fenech et al., 2012). BB and CC represent biomass burning and coal combustion, respectively. The light purple squares represent nitrate isotope data in cloud water (this study). (b) The 25th percentiles, median, and 75th percentiles for the $\delta^{15} \mathrm{~N}$ values of the ambient $\mathrm{NH}_{3}$ (Chang et al., 2016; Felix et al., 2013; Savard et al., 2018; Smirnoff et al., 2012) and $\mathrm{NH}_{4}^{+}$in precipitation (Fang et al., 2011; Leng et al., 2018; Yang et al., 2014; Zhang et al., 2008), cloud water (this study), $\mathrm{PM}_{2.5}$ (particulate matter with aerodynamic diameter less than $2.5 \mu \mathrm{m}$; Lin et al., 2016; Park et al., 2018; Proemse et al., 2012; Smirnoff et al., 2012), and TSPs (total suspended particles with aerodynamic diameter less than $100 \mu \mathrm{m}$ (Kundu et al., 2010; Savard et al., 2018; Yeatman et al., 2001) are shown.

for the $\mathrm{N}$ isotope enrichment factor associated with the con-

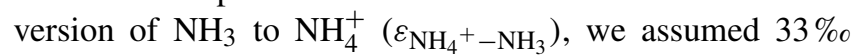
when using MixSIR but also considered lower values for $\varepsilon_{\mathrm{NH}_{4}{ }^{+}-\mathrm{NH}_{3}}$ (Fig. 3a) (given the conflicting evidence with regards to $\varepsilon_{\mathrm{NH}_{4}{ }^{+}-\mathrm{NH}_{3}}$; e.g., Deng et al., 2018; Li et al., 2012). Dependent of the choice for $\varepsilon_{\mathrm{NH}_{4}}{ }^{+}-\mathrm{NH}_{3}$ (between $0 \%$ and $33 \%$ proposed by Heaton et al., 1997) the relative contribution of biomass burning, fertilizer application, and livestock breeding to $\mathrm{NH}_{4}^{+}$in cloud water ranges from $25.9 \%$ to $85.4 \%, 5.9 \%$ to $37.0 \%$, and $8.7 \%$ to $85.4 \%$, respectively. Ir-

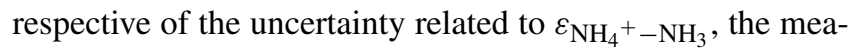
surement of levoglucosan provides compelling evidence that biomass burning represents an important $\mathrm{NH}_{3}$ source, independently validating our isotope approach. Our sampling site is located in the North China Plain, also known as the granary of China. Although nonagricultural $\mathrm{NH}_{3}$ emissions like on-road traffic are important in the urban atmosphere (Chang et al., 2016), their contribution must be considered insignifi- cant with respect to fertilizer application and livestock breeding in this region (Kang et al., 2016). Besides, coal-based heating in China is suspended during summertime, and coal combustion has been demonstrated to be a minor contributor of total $\mathrm{NH}_{3}$ emissions (Li et al., 2016a). Hence the partitioning between the three main $\mathrm{NH}_{3}$ sources appears plausible. Moreover, existing emission inventory data confirm that the ratio of $\mathrm{NH}_{3}$ emissions in the North China Plain from livestock breeding $(1658 \mathrm{kt})$ and fertilizer application (1413 kt) was 1.17 (Zhang et al., 2010), which is very close

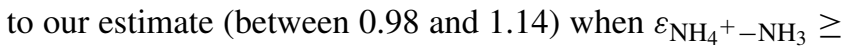
$25 \%$. For a $\varepsilon_{\mathrm{NH}_{4}+-\mathrm{NH}_{3}}$ range that we consider most plausible (i.e., between $25 \%$ and $33 \%$ ), the relative cloud water $\mathrm{NH}_{4}^{+}$source partitioning between biomass burning, fertilizer application, and livestock is $32.9 \% \pm 4.6 \%, 32.9 \% \pm 3.0 \%$, and $34.2 \% \pm 1.6 \%$, respectively (indicated as red square in Fig. 3a). It is important to note that a large uncertainty existed with regards to the assessment of biomass burning, which can partly be attributed to the lack of localized isotopic source signatures in China. In addition, the isotopic fractionation from the conversion of $\mathrm{NH}_{3}$ to $\mathrm{NH}_{4}^{+}$was approximated in this study, and it was not possible to incorporate all of the possible equilibrium and kinetic fractionation scenarios.

The computational quantum chemistry (CQC) module in MixSIR has proven to be a robust tool to quantify the $\mathrm{N}$ isotope enrichment factor during $\mathrm{NO}_{x}-\mathrm{NO}_{3}^{-}$conversion $\left(\varepsilon_{\mathrm{NO}_{3}{ }^{-}-\mathrm{NO}_{x}}\right)$ (e.g., Zong et al., 2017; Chang et al., 2018). Cloud water sample-based data from this study reveal that $\varepsilon_{\mathrm{NO}_{3}{ }^{-}-\mathrm{NO}_{x}}$ values fall into a small range (5.21\%o to $5.98 \%$ ) (Fig. 3b), suggesting robust isotope effects during the $\mathrm{N}$ iso-

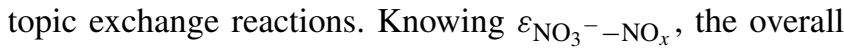
contribution of various $\mathrm{NO}_{x}$ sources to $\mathrm{NO}_{3}^{-}$in cloud water can be estimated (Fig. 3c). As was expected, biomass burning was the largest contributor $(28.2 \% \pm 2.7 \%)$, followed by on-road traffic $(27.1 \% \pm 2.2 \%)$, coal combustion $(26.8 \% \pm 3.4 \%)$, and biogenic soil $(17.9 \% \pm 3.9 \%)$. The fundamental importance of biomass-burning-emitted $\mathrm{NO}_{x}$ to $\mathrm{NO}_{3}^{-}$in cloud water is supported by the observed correlation between the concentrations of levoglucosan and biomassburning-derived $\mathrm{NO}_{3}^{-}\left(r^{2}=0.66\right)$. The average contribution ratio of coal combustion and on-road transportation to $\mathrm{NO}_{x}$ emissions in our study (0.99) is slightly lower 

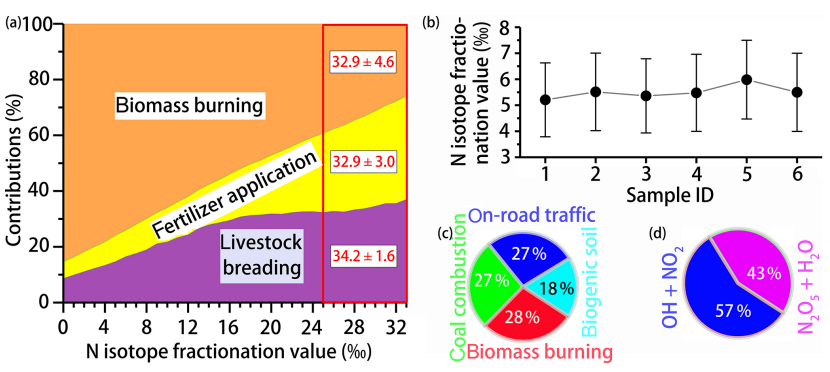

Figure 3. (a) Source partitioning estimates for $\mathrm{NH}_{4}^{+}$in cloud wa-

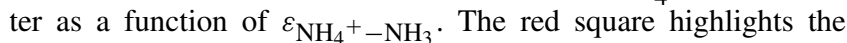
best-guess estimates based on $\varepsilon_{\mathrm{NH}_{4}}{ }_{-}-\mathrm{NH}_{3} \geq 25 \%$ o. (b) Whisker plot of the $\mathrm{N}$ fractionation for the conversation of $\mathrm{NO}_{x}$ to $\mathrm{NO}_{3}^{-}$

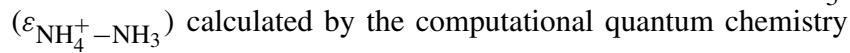
(CQC) module. The upper line, dot, and bottom line indicate the 25 th percentile, median, and 75th percentile, respectively. Refer to Table 1 for sample ID. (c) Overall contribution of various $\mathrm{NO}_{x}$ sources to $\mathrm{NO}_{3}^{-}$in cloud water as estimated by the MixSIR model. (d) Overall contribution of the two dominant pathways to $\mathrm{NO}_{3}^{-}$formation in cloud water, as estimated by the MixSIR model.

than that calculated from regional emission inventories $(9.0 \mathrm{Tg} / 7.4 \mathrm{Tg}=1.22)$ (Zhao et al., 2013). The apparent difference is likely real and reflects the fact that $\mathrm{NO}_{x}$ emissions by anthropogenic activities changed significantly since 2010: a $17 \%$ total emission decrease between 2010 and 2017 can primarily be attributed to upgraded emission standards and new "ultra-low emission" techniques in the coalfired power plant sector, and given that $\mathrm{NO}_{x}$ emitted from traffic likely increased as a consequence of the continuous expansion of the auto trade market during the last decade (Chang et al., 2018). In turn, our source partitioning estimate probably reflects the most updated status of $\mathrm{NO}_{x}$ emissions in China, where transportation-related $\mathrm{NO}_{x}$ emissions have reached levels that are comparable to $\mathrm{NO}_{x}$ emissions by coal combustion. In this regard, our study demonstrates that Bayesian-based isotopic mixing modeling can be an effective and timely approach to track rapid emission changes in $\mathrm{NO}_{x}$ in a fast-developing country like China.

Using the measured $\delta^{18} \mathrm{O}$ and Eqs. (1)-(4) (and the assumptions above), we can calculate $\gamma$ and the relative importance of the two oxidation pathways of $\mathrm{NO}_{3}^{-}$formation (Fig. 3d). On average, $57 \% \mathrm{NO}_{3}^{-}$formation can be attributed to the " $\mathrm{NO}_{2}+\mathrm{OH}$ " pathway and $43 \%$ to the " $\mathrm{N}_{2} \mathrm{O}_{5}+\mathrm{H}_{2} \mathrm{O}$ " pathway. In the low-latitude regions, where atmospheric $\mathrm{OH}$ concentrations are highest, particulate $\mathrm{NO}_{3}^{-}$production via the $\mathrm{NO}_{2}+\mathrm{OH}$ pathway predominates (up to $87 \%$ ) (Alexander et al., 2009). Sampling during summertime, oxidation of $\mathrm{NO}_{2}$ through $\mathrm{OH}$ was expected to be the dominant pathway of nitrate formation, in accordance with observations from the subtropics (Hastings et al., 2003). However, our results highlight that $\mathrm{N}_{2} \mathrm{O}_{5}$ hydrolysis can be an almost equally important process as the oxidization of $\mathrm{NO}_{2}$ with $\mathrm{OH}$ with regards to the $\mathrm{NO}_{3}^{-}$formation in cloud water (Wang et al., 2017b).

\section{Conclusions}

In this study, we measured the isotopic composition of nitrogenous species in cloud water at the summit of Mt. Tai during a long-lasting biomass burning event in order to investigate the sources and processes involved in cloud water $\mathrm{NO}_{3}^{-} / \mathrm{NH}_{4}^{+}$formation, and in turn to test our isotope-balance approach to constrain $\mathrm{N}$ source partitioning in cloud water. Using a Bayesian isotope mixing model, the $\delta^{15} \mathrm{~N}$-based estimates confirm that at least transiently biomass-burningrelated $\mathrm{NH}_{3}$ and $\mathrm{NO}_{x}$ emissions are a major source of cloud water N. Moreover, our data are in accordance with regional emission inventories for both $\mathrm{NH}_{3}$ and $\mathrm{NO}_{x}$, validating the Bayesian isotope mixing model approach. Based on cloud water nitrate $\delta^{18} \mathrm{O}$ measurements, the reaction of $\mathrm{NO}_{2}$ with $\mathrm{OH}$ turned out to be the dominant pathway to form cloud nitrate, yet the contribution from the heterogeneous hydrolysis of $\mathrm{N}_{2} \mathrm{O}_{5}$ to $\mathrm{NO}_{3}^{-}$is almost equally important. Our study underscores the value of cloud-water-dissolved inorganic nitrogen isotopes as carriers of quantitative information on regional $\mathrm{NO}_{x}$ emissions. It sheds light on the origin and production pathways of nitrogenous species in clouds and emphasizes the importance of BB-derived nitrogenous species as cloud condensation nuclei in China's troposphere. Moreover, it highlights the rapid evolution of $\mathrm{NO}_{x}$ emissions in China. Despite an overall reduction in total anthropogenic $\mathrm{NO}_{x}$ emissions due to effective emission control actions and stricter emission standards for vehicles, the relative contribution of transportation to total $\mathrm{NO}_{x}$ emissions has increased over the last decade and may already have exceeded emissions from the power sector. 


\section{Appendix A: Bayesian isotopic mixing model}

The Bayesian mixing model makes use of stable isotope data to determine the probability distribution of source contributions to a mixture, explicitly accounting for uncertainties associated with multiple sources, their isotopic signatures, and isotope fractionation during transformations. The model has been widely used in ecological studies, such as food-web analyses. In the Bayesian theorem, the contribution of each source is calculated based on mixed data and prior information, such that

$P\left(f_{\mathrm{q}} \mid\right.$ data $)=\theta\left(\right.$ data $\left.\mid f_{\mathrm{q}}\right) \times p\left(f_{\mathrm{q}}\right) / \sum \theta\left(\right.$ data $\left.\mid f_{\mathrm{q}}\right) \times p\left(f_{\mathrm{q}}\right)$,

where $\theta\left(\right.$ data $\left.\mid f_{\mathrm{q}}\right)$ and $p\left(f_{\mathrm{q}}\right)$ refer to the likelihood of the given mixed isotope signature and the predetermined probability of the given state of nature, based on prior information, respectively. The denominator represents the numerical approximation of the marginal probability of the data. In a Bayesian model (stable isotope in R, SIAR), isotope signatures from the mixed data pool are assumed to be normally distributed. Uncertainty in the distribution of isotope sources and associated isotope fractionation during transformations are factored into the model by defining respective mean $(\mu)$ and standard deviation $(\sigma)$ parameters. Prior knowledge about proportional source contributions $\left(f_{\mathrm{q}}\right)$ is parameterized using the Dirichlet distribution, with an interval of $[0,1]$. To assess the likelihood of the given $f_{\mathrm{q}}$, the proposed proportional contribution is combined with a userspecified isotope distribution of sources and their associated isotope effects to develop a proposed isotope distribution for the mixture. The probability of fractional source contributions $\left(f_{\mathrm{q}}\right)$ is calculated by the Hilborn sampling-importanceresampling method. 
Appendix B: Isotopic signatures of $\mathrm{NO}_{x}$ emitted from various sources

Table B1. Typical $\delta^{15} \mathrm{~N}-\mathrm{NO}_{x}$ values for coal combustion, transportation, biomass burning, and soils based on literature values.

\begin{tabular}{lrrrl}
\hline Source types & Mean (\%o) & Standard (\%o) & Number & Reference \\
\hline Coal combustion & 13.72 & 4.57 & 47 & Felix et al. (2012, 2015) \\
Transportation & -7.25 & 7.80 & 151 & Walter et al. (2015a, b), \\
& & & & Heaton et al. (1997) \\
Biomass burning & 1.04 & 4.13 & 24 & Fibiger and Hastings (2016), \\
& & & & Felix and Elliott (2013) \\
Biogenic soil & -33.77 & 12.16 & 6 & Hastings et al. (2009), \\
& & & Felix et al. (2012) \\
\hline
\end{tabular}


Data availability. All data used to support the conclusion are presented in this paper. Additional data are available upon request; please contact the corresponding authors (Yanlin Zhang (dryanlinzhang@outlook.com) and Jianmin Chen (jmchen@fudan.edu.cn)).

Author contributions. YZ and JC designed the study. YC and YL conceived the study. YC, JL, LS, XZ, WZ, TH and CZ carried out the field experiments and laboratory analysis. YC wrote the paper with ML and YZ. All the authors contributed to the interpretation of the results obtained with the new approach here described and revised the paper content, giving final approval of the version to be submitted. YC and ML addressed the reviewers' comments.

Competing interests. The authors declare that they have no conflict of interest.

Special issue statement. This article is part of the special issue "Regional transport and transformation of air pollution in eastern China". It is not associated with a conference.

Financial support. This study was supported by the National Key R\&D Program of China (grant no. 2017YFC0212704), the National Natural Science Foundation of China (grant nos. 41975166, 41705100, 91644103, 41761144056, 91644103), the Provincial Natural Science Foundation of Jiangsu (grant nos. BK20180040, BK20170946), the University Science Research Project of Jiangsu Province (17KJB170011), the University of Basel research funds, the Joint Open Project of KLME \& CICFEMD, NUIST (KLME201909), the opening project of Shanghai Key Laboratory of Atmospheric Particle Pollution and Prevention $\left(\mathrm{LAP}^{3}\right)$, and the special fund of the State Key Joint Laboratory of Environment Simulation and Pollution Control (grant no. 19K01ESPCT).

Review statement. This paper was edited by Sergey A. Nizkorodov and reviewed by three anonymous referees.

\section{References}

Alexander, B., Hastings, M. G., Allman, D. J., Dachs, J., Thornton, J. A., and Kunasek, S. A.: Quantifying atmospheric nitrate formation pathways based on a global model of the oxygen isotopic composition $\left(\Delta^{17} \mathrm{O}\right)$ of atmospheric nitrate, Atmos. Chem. Phys., 9, 5043-5056, https://doi.org/10.5194/acp-9-5043-2009, 2009.

Anenberg, S. C., Miller, J., Minjares, R., Du, L., Henze, D. K., Lacey, F., Malley, C. S., Emberson, L., Franco, V., Klimont, Z., and Heyes, C.: Impacts and mitigation of excess diesel-related $\mathrm{NO}_{x}$ emissions in 11 major vehicle markets, Nature, 545, 467471, 2017.
Balasubramanian, S., Koloutsou-Vakakis, S., McFarland, D. M., and Rood, M. J.: Reconsidering emissions of ammonia from chemical fertilizer usage in Midwest USA, J. Geophys. Res., 120, 6232-6246, 2015.

Benkovitz, C. M., Scholtz M. T., Pacyna J., Tarrasón L., Dignon J., Voldner E. C., Spiro P. A., Logan J. A., and Graedel T. E.: Global gridded inventories of anthropogenic emissions of sulfur and nitrogen, J. Geophys. Res., 101, 29239-29253, https://doi.org/10.1029/96JD00126, 1996.

Boone, E. J., Laskin, A., Laskin, J., Wirth, C., Shepson, P. B., Stirm, B. H., and Pratt, K. A.: Aqueous processing of atmospheric organic particles in cloud water collected via aircraft sampling, Environ. Sci. Technol., 49, 8523-8530, https://doi.org/10.1021/acs.est.5b01639, 2015.

Bouwman, A., Lee, D., Asman, W., Dentener, F., Van Der Hoek, K., and Olivier, J.: A global high-resolution emission inventory for ammonia, Global Biogeochem. Cy., 11, 561-587, https://doi.org/10.1029/97GB02266, 1997.

Cao, F., Zhang, S. C., Kawamura, K., and Zhang, Y. L.: Inorganic markers, carbonaceous components and stable carbon isotope from biomass burning aerosols in Northeast China, Sci. Total Environ., 572, 1244-1251, https://doi.org/10.1016/j.scitotenv.2015.09.099, 2016, 2016.

Cao, F., Zhang, S. C., Kawamura, K., Liu, X., Yang, C., Xu, Z., Fan, M., Zhang, W., Bao, M., Chang, Y., Song, W., Liu, S., Lee, X., Li, J., Zhang, G., and Zhang, Y. L.: Chemical characteristics of dicarboxylic acids and related organic compounds in $\mathrm{PM}_{2.5}$ during biomass-burning and non-biomass-burning seasons at a rural site of Northeast China, Environ. Pollut., 231, 654-662, https://doi.org/10.1016/j.envpol.2017.08.045, 2017.

Chang, Y. H., Liu, X., Deng, C., Dore, A. J., and Zhuang, G.: Source apportionment of atmospheric ammonia before, during, and after the 2014 APEC summit in Beijing using stable nitrogen isotope signatures, Atmos. Chem. Phys., 16, 11635-11647, https://doi.org/10.5194/acp-16-11635-2016, 2016.

Chang, Y. H., Zhang, Y., Tian, C., Zhang, S., Ma, X., Cao, F., Liu, X., Zhang, W., Kuhn, T., and Lehmann, M. F.: Nitrogen isotope fractionation during gas-to-particle conversion of $\mathrm{NO}_{x}$ to $\mathrm{NO}_{3}^{-}$in the atmosphere - implications for isotope-based $\mathrm{NO}_{x}$ source apportionment, Atmos. Chem. Phys., 18, 1164711661, https://doi.org/10.5194/acp-18-11647-2018, 2018.

Chellman, N. J., Hastings, M. G., and McConnell, J. R.: Increased nitrate and decreased $\delta^{15} \mathrm{~N}-\mathrm{NO}_{3}^{-}$in the Greenland Arctic after 1940 attributed to North American oil burning, The Cryosphere Discuss., https://doi.org/10.5194/tc-2016-163, 2016.

Chen, J. M., Li, C., Ristovski, Z., Milic, A., Gu, Y., Islam, M. S., Wang, S., Hao, J., Zhang, H., He, C., Guo, H., Fu, H., Miljevic, B., Morawska, L., Thai, P., Lam, Y. F., Pereira, G., Ding, A., Huang, X., and Dumka, U. C.: A review of biomass burning: Emissions and impacts on air quality, health and climate in China, Sci. Total Environ., 579, 1000-1034, https://doi.org/10.1016/j.scitotenv.2016.11.025, 2017.

Chen, Y. C., Christensen, M. W., Stephens, G. L., and Seinfeld, J. H.: Satellite-based estimate of global aerosol-cloud radiative forcing by marine warm clouds, Nat. Geosci., 7, 643, https://doi.org/10.1038/ngeo2214, 2014.

Crutzen, P. J. and Andreae, M. O.: Biomass burning in the tropics: Impact on atmospheric chemistry 
and biogeochemical cycles, Science, 250, 1669-1678, https://doi.org/10.1126/science.250.4988.1669, 1990.

Demoz, B. B., Collett, J. L., and Daube, B. C.: On the Caltech active strand cloudwater collectors, Atmos. Res., 41, 47-62, https://doi.org/10.1016/0169-8095(95)00044-5, 1996.

Deng, Y., Li, Y., and Li, L.: Experimental investigation of nitrogen isotopic effects associated with ammonia degassing at $0-70^{\circ} \mathrm{C}$, Geochim. Cosmochim. Ac., 226, 182-191, https://doi.org/10.1016/j.gca.2018.02.007, 2018

Desyaterik, Y., Sun, Y., Shen, X., Lee, T., Wang, X., Wang, T., and Collett, J. L.: Speciation of "brown" carbon in cloud water impacted by agricultural biomass burning in eastern China, J. Geophys. Res., 118, 7389-7399, https://doi.org/10.1002/jgrd.50561, 2013.

Duncan, B. N., Lamsal, L. N., Thompson, A. M., Yoshida, Y., Lu, Z., Streets, D. G., Hurwitz, M. M., and Pickering, K. E.: A spacebased, high-resolution view of notable changes in urban $\mathrm{NO}_{x}$ pollution around the world (2005-2014), J. Geophys. Res., 121, 976-996, 2016.

Elliott, E., Kendall, C., Wankel, S. D., Burns, D., Boyer, E., Harlin, K., Bain, D., and Butler, T.: Nitrogen isotopes as indicators of $\mathrm{NO}_{x}$ source contributions to atmospheric nitrate deposition across the Midwestern and northeastern United States, Environ. Sci. Technol., 41, 7661-7667, https://doi.org/10.1021/es070898t, 2007.

Elliott, E. M., Kendall, C., Boyer, E. W., Burns, D. A., Lear, G. G., Golden, H. E., Harlin, K., Bytnerowicz, A., Butler, T. J., and Glatz, R.: Dual nitrate isotopes in dry deposition: Utility for partitioning $\mathrm{NO}_{x}$ source contributions to landscape nitrogen deposition, J. Geophys. Res., 114, G04020, https://doi.org/10.1029/2008jg000889, 2009.

Fang, Y. T., Koba, K., Wang, X. M., Wen, D. Z., Li, J., Takebayashi, Y., Liu, X. Y., and Yoh, M.: Anthropogenic imprints on nitrogen and oxygen isotopic composition of precipitation nitrate in a nitrogen-polluted city in southern China, Atmos. Chem. Phys., 11, 1313-1325, https://doi.org/10.5194/acp-111313-2011, 2011.

Felix, J. D. and Elliott, E. M.: The agricultural history of human-nitrogen interactions as recorded in ice core $\delta^{15} \mathrm{~N}^{-\mathrm{NO}_{3}^{-}}$, Geophys. Res. Lett., 40, 1642-1646, https://doi.org/10.1002/grl.50209, 2013.

Felix, J. D., Elliott, E. M., and Shaw, S. L.: Nitrogen isotopic composition of coal-fired power plant $\mathrm{NO}_{x}$ : Influence of emission controls and implications for global emission inventories, Environ. Sci. Technol., 46, 3528-3535, https://doi.org/10.1021/es203355v, 2012.

Felix, J. D., Elliott, E. M., Gish, T. J., McConnell, L. L., and Shaw, S. L.: Characterizing the isotopic composition of atmospheric ammonia emission sources using passive samplers and a combined oxidation-bacterial denitrifier approach, Rapid Commun. Mass Sp., 27, 2239-2246, https://doi.org/10.1002/rcm.6679, 2013.

Felix, J. D., Elliott, E. M., Avery, G. B., Kieber, R. J., Mead, R. N., Willey, J. D., and Mullaugh, K. M.: Isotopic composition of nitrate in sequential Hurricane Irene precipitation samples: Implications for changing $\mathrm{NO}_{x}$ sources, Atmos. Environ., 106, 191195, https://doi.org/10.1016/j.atmosenv.2015.01.075, 2015.

Fenech, C., Rock, L., Nolan, K., Tobin, J., and Morrissey, A.: The potential for a suite of isotope and chemical markers to differen- tiate sources of nitrate contamination: a review, Water Res., 46, 2023-2041, https://doi.org/10.1016/j.watres.2012.01.044, 2012.

Fibiger, D. L. and Hastings, M. G.: First measurements of the nitrogen isotopic composition of $\mathrm{NO}_{x}$ from biomass burning, Environ. Sci. Technol., 50, 11569-11574, https://doi.org/10.1021/acs.est.6b03510, 2016.

Fomba, K. W., van Pinxteren, D., Müller, K., Iinuma, Y., Lee, T., Collett Jr., J. L., and Herrmann, H.: Trace metal characterization of aerosol particles and cloud water during HCCT 2010, Atmos. Chem. Phys., 15, 8751-8765, https://doi.org/10.5194/acp15-8751-2015, 2015.

Gioda, A., Reyes-Rodríguez, G. J., Santos-Figueroa, G., Collett, J. L., Decesari, S., Ramos, M. D. C. K. V., Bezerra Netto, H. J. C., de Aquino Neto, F. R., and Mayol-Bracero, O. L.: Speciation of water-soluble inorganic, organic, and total nitrogen in a background marine environment: Cloud water, rainwater, and aerosol particles, J. Geophys. Res., 116, D05203, https://doi.org/10.1029/2010JD015010, 2011.

Hastings, M., Sigman, D. M., and Lipschultz, F.: Isotopic evidence for source changes of nitrate in rain at Bermuda, J. Geophys. Res., 108, 4790, https://doi.org/10.1029/2003JD003789, 2003.

Hastings, M., Jarvis, J., and Steig, E.: Anthropogenic impacts on nitrogen isotopes of ice-core nitrate, Science, 324, 1288, https://doi.org/10.1126/science.1170510, 2009.

Hastings, M., Casciotti, K. L., and Elliott, E. M.: Stable isotopes as tracers of anthropogenic nitrogen sources, deposition, and impacts, Elements, 9, 339-344, https://doi.org/10.2113/gselements.9.5.339, 2013.

Heald, C. L., Collett Jr., J. L., Lee, T., Benedict, K. B., Schwandner, F. M., Li, Y., Clarisse, L., Hurtmans, D. R., Van Damme, M., Clerbaux, C., Coheur, P.-F., Philip, S., Martin, R. V., and Pye, H. O. T.: Atmospheric ammonia and particulate inorganic nitrogen over the United States, Atmos. Chem. Phys., 12, 10295-10312, https://doi.org/10.5194/acp-12-10295-2012, 2012.

Heaton, T. H. E., Spiro, B., and Robertson, S. M. C.: Potential canopy influences on the isotopic composition of nitrogen and sulphur in atmospheric deposition, Oecologia, 109, 600-607, https://doi.org/10.1007/s004420050122, 1997.

Herrmann, H., Schaefer, T., Tilgner, A., Styler, S. A., Weller, C., Teich, M., and Otto, T.: Tropospheric aqueous-phase chemistry: Kinetics, mechanisms, and its coupling to a changing gas phase, Chem. Rev., 115, 4259-4334, https://doi.org/10.1021/cr500447k, 2015.

Hoffmann, D., Tilgner, A., Iinuma, Y., and Herrmann, H.: Atmospheric stability of levoglucosan: A detailed laboratory and modeling study, Environ. Sci. Technol., 44, 694-699, https://doi.org/10.1021/es902476f, 2010.

Huang, C., Chen, C. H., Li, L., Cheng, Z., Wang, H. L., Huang, H. Y., Streets, D. G., Wang, Y. J., Zhang, G. F., and Chen, Y. R.: Emission inventory of anthropogenic air pollutants and VOC species in the Yangtze River Delta region, China, Atmos. Chem. Phys., 11, 4105-4120, https://doi.org/10.5194/acp11-4105-2011, 2011.

Jaegle, L., Steinberger, L., Martin, R. V., and Chance, K.: Global partitioning of $\mathrm{NO}_{x}$ sources using satellite observations: Relative roles of fossil fuel combustion, biomass burning and soil emissions, Faraday Discus., 130, 407-423, 2005.

Kang, Y., Liu, M., Song, Y., Huang, X., Yao, H., Cai, X., Zhang, H., Kang, L., Liu, X., Yan, X., He, H., Zhang, Q., Shao, M., 
and Zhu, T.: High-resolution ammonia emissions inventories in China from 1980 to 2012, Atmos. Chem. Phys., 16, 2043-2058, https://doi.org/10.5194/acp-16-2043-2016, 2016.

Kawashima, H. and Kurahashi, T.: Inorganic ion and nitrogen isotopic compositions of atmospheric aerosols at Yurihonjo, Japan: Implications for nitrogen sources, Atmos. Environ., 45, 63096316, https://doi.org/10.1016/j.atmosenv.2011.08.057, 2011.

Kim, I. N., Lee, K., Gruber, N., Karl, D. M., Bullister, J. L., Yang, S., and Kim, T. W.: Increasing anthropogenic nitrogen in the North Pacific Ocean, Science, 346, 1102-1106, https://doi.org/10.1126/science.1258396, 2014.

Kundu, S., Kawamura, K., and Lee, M.: Seasonal variation of the concentrations of nitrogenous species and their nitrogen isotopic ratios in aerosols at Gosan, Jeju Island: Implications for atmospheric processing and source changes of aerosols, J. Geophys. Res., 115, D20305, https://doi.org/10.1029/2009JD013323, 2010.

Lamsal, L. N., Martin, R. V., Padmanabhan, A., van Donkelaar, A., Zhang, Q., Sioris, C. E., Chance, K., Kurosu, T. P., and Newchurch, M. J.: Application of satellite observations for timely updates to global anthropogenic $\mathrm{NO}_{x}$ emission inventories, Geophys. Res. Lett., 38, L05810, https://doi.org/10.1029/2010GL046476, 2011.

Lance, S., Barth, M., and Carlton, A.: Multiphase chemistry: Experimental design for coordinated measurement and modeling studies of cloud processing at a mountaintop, B. Am. Meteorol. Soc., 98, ES163-ES167, https://doi.org/10.1175/bams-d-170015.1, 2017.

Leng, Q., Cui, J., Zhou, F., Du, K., Zhang, L., Fu, C., Liu, Y., Wang, H., Shi, G., Gao, M., Yang, F., and He, D.: Wet-only deposition of atmospheric inorganic nitrogen and associated isotopic characteristics in a typical mountain area, southwestern China, Sci. Total Environ., 616, 55-63, https://doi.org/10.1016/j.scitotenv.2017.10.240, 2018.

Levy, H., Moxim, W. J., and Kasibhatla, P. S.: A global threedimensional time-dependent lightning source of tropospheric $\mathrm{NO}_{x}$, J. Geophys. Res., 101, 22911-22922, 1996.

Li, J., Wang, X., Chen, J., Zhu, C., Li, W., Li, C., Liu, L., Xu, C., Wen, L., Xue, L., Wang, W., Ding, A., and Herrmann, H.: Chemical composition and droplet size distribution of cloud at the summit of Mount Tai, China, Atmos. Chem. Phys., 17, 9885-9896, https://doi.org/10.5194/acp-17-9885-2017, 2017.

Li, L., Lollar, B. S., Li, H., Wortmann, U. G., and LacrampeCouloume, G.: Ammonium stability and nitrogen isotope fractionations for $\mathrm{NH}_{3}$ (aq)- $\mathrm{NH}_{3}$ (gas) systems at $20-70{ }^{\circ} \mathrm{C}$ and $\mathrm{pH}$ of 2-13: Applications to habitability and nitrogen cycling in lowtemperature hydrothermal systems, Geochim. Cosmochim. Ac., 84, 280-296, https://doi.org/10.1016/j.gca.2012.01.040, 2012.

Li, Q., Jiang, J., Cai, S., Zhou, W., Wang, S., Duan, L., and Hao, J.: Gaseous ammonia emissions from coal and biomass combustion in household stoves with different combustion efficiencies, Environ. Sci. Technol. Lett., 3, 98-103, https://doi.org/10.1021/acs.estlett.6b00013, 2016a.

Li, T., Wang, Y., Mao, H., Wang, S., Talbot, R. W., Zhou, Y., Wang, Z., Nie, X., and Qie, G.: Insights on chemistry of mercury species in clouds over Northern China: Complexation and adsorption, Environ. Sci. Technol., 52, 5125-5134, https://doi.org/10.1021/acs.est.7b06669, 2018.
Li, Y., Schichtel, B. A., Walker, J. T., Schwede, D. B., Chen, X., Lehmann, C. M. B., Puchalski, M. A., Gay, D. A., and Collett, J. L.: Increasing importance of deposition of reduced nitrogen in the United States, P. Natl. Acad. Sci. USA, 113, 5874-5879, https://doi.org/10.1073/pnas.1525736113, 2016b.

Lin, C. T., Jickells, T. D., Baker, A. R., Marca, A., and Johnson, M. T.: Aerosol isotopic ammonium signatures over the remote Atlantic Ocean, Atmos. Environ., 133, 165-169, https://doi.org/10.1016/j.atmosenv.2016.03.020, 2016.

Lin, Q., Zhang, G., Peng, L., Bi, X., Wang, X., Brechtel, F. J., Li, M., Chen, D., Peng, P., Sheng, G., and Zhou, Z.: In situ chemical composition measurement of individual cloud residue particles at a mountain site, southern China, Atmos. Chem. Phys., 17, 84738488, https://doi.org/10.5194/acp-17-8473-2017, 2017.

Liu, D., Fang, Y., Tu, Y., and Pan, Y.: Chemical method for nitrogen isotopic analysis of ammonium at natural abundance, Anal. Chem., 86, 3787-3792, https://doi.org/10.1021/ac403756u, 2014.

Liu, X., Zhang, Y., Han, W., Tang, A., Shen, J., Cui, Z., Vitousek, P., Erisman, J. W., Goulding, K., Christie, P., Fangmeier, A., and Zhang, F.: Enhanced nitrogen deposition over China, Nature, 494, 459-462, https://doi.org/10.1038/nature11917, 2013.

Liu, L., Zhang, J., Xu, L., Yuan, Q., Huang, D., Chen, J., Shi, Z., Sun, Y., Fu, P., Wang, Z., Zhang, D., and Li, W.: Cloud scavenging of anthropogenic refractory particles at a mountain site in North China, Atmos. Chem. Phys., 18, 14681-14693, https://doi.org/10.5194/acp-18-14681-2018, 2018.

Lobert, J. M., Scharffe, D. H., Hao, W. M., and Crutzen, P. J.: Importance of biomass burning in the atmospheric budgets of nitrogen-containing gases. Nature, 346, 552, https://doi.org/10.1038/346552a0, 1990.

McIlvin, M. R. and Altabet, M. A.: Chemical conversion of nitrate and nitrite to nitrous oxide for nitrogen and oxygen isotopic analysis in freshwater and seawater, Anal. Chem., 77, 5589-5595, https://doi.org/10.1021/ac050528s, 2005.

Michalski, G., Bockheim, J. G., Kendall, C., and Thiemens, M.: Isotopic composition of Antarctic Dry Valley nitrate: Implications for $\mathrm{NO}_{y}$ sources and cycling in Antarctica, Geophys. Res. Lett., 32, L13817, https://doi.org/10.1029/2004GL022121, 2005.

Michalski, G., Bhattacharya, S., and Mase, F.: Oxygen isotope dynamics of atmospheric nitrate and its precursor molecules (Chapter 30), in: Handbook of Environmental Isotope Geochemistry, edited by: Baskaran, M., Advances in Isotope Geochemistry, https://doi.org/10.1007/978-3-642-10637-8_30, SpringerVerlag, Berlin Heidelberg, 2011.

Miyazaki, K., Eskes, H., Sudo, K., Boersma, K. F., Bowman, K., and Kanaya, Y.: Decadal changes in global surface $\mathrm{NO}_{x}$ emissions from multi-constituent satellite data assimilation, Atmos. Chem. Phys., 17, 807-837, https://doi.org/10.5194/acp-17-8072017, 2017.

Morin, S., Savarino, J., Frey, M. M., Yan, N., Bekki, S., Bottenheim, J. W., and Martins, J. M.: Tracing the origin and fate of $\mathrm{NO}_{x}$ in the Arctic atmosphere using stable isotopes in nitrate. Science, 322, 730-732, https://doi.org/10.1126/science.1161910, 2008.

Morino, Y., Kondo, Y., Takegawa, N., Miyazaki, Y., Kita, K., Komazaki, Y., Fukuda, M., Miyakawa, T., Moteki, N., and Worsnop, D. R.: Partitioning of $\mathrm{HNO}_{3}$ and particulate nitrate over Tokyo: Effect of vertical mixing, J. Geophys. Res., 111, D15215, https://doi.org/10.1029/2005JD006887, 2006. 
Norris, J. R., Allen, R. J., Evan, A. T., Zelinka, M. D., O'Dell, C. W., and Klein, S. A.: Evidence for climate change in the satellite cloud record. Nature, 536, 72, https://doi.org/10.1038/nature18273, 2016.

Okin, G. S., Baker, A. R., Tegen, I., Mahowald, N. M., Dentener, F. J., Duce, R. A., Galloway, J. N., Hunter, K., Kanakidou, M., Kubilay, N., Prospero, J. M., Sarin, M., Surapipith, V., Uematsu, M., and Zhu, T.: Impacts of atmospheric nutrient deposition on marine productivity: Roles of nitrogen, phosphorus, and iron. Global Biogeochem. Cy., 25, GB2022, https://doi.org/10.1029/2010GB003858, 2011.

Olivier, J., Bouwman, A., Van der Hoek, K., and Berdowski, J.: Global air emission inventories for anthropogenic sources of $\mathrm{NO}_{x}, \mathrm{NH}_{3}$ and $\mathrm{N}_{2} \mathrm{O}$ in 1990, Environ. Pollut., 102, 135-148, https://doi.org/10.1016/B978-0-08-043201-4.50024-1, 1998.

Park, Y., Park, K., Kim, H., Yu, S., Noh, S., Kim, M., Kim, J., Ahn, J., Lee, M., Seok, K., and Kim, Y.: Characterizing isotopic compositions of TC-C, $\mathrm{NO}_{3}^{-}-\mathrm{N}$, and $\mathrm{NH}_{4}^{+}-\mathrm{N}$ in $\mathrm{PM}_{2.5}$ in South Korea: Impact of China's winter heating, Environ. Pollut., 233, 735744, https://doi.org/10.1016/j.envpol.2017.10.072, 2018.

Paulot, F. and Jacob, D. J.: Hidden cost of US agricultural exports: particulate matter from ammonia emissions, Environ. Sci. Technol., 48, 903-908, 2014.

Price, C., Penner, J., and Prather, M.: $\mathrm{NO}_{x}$ from lightning: 1. Global distribution based on lightning physics, J. Geophys. Res., 102, 5929-5941, 1997.

Proemse, B. C., Mayer, B., Chow, J. C., and Watson, J. G.: Isotopic characterization of nitrate, ammonium and sulfate in stack $\mathrm{PM}_{2.5}$ emissions in the Athabasca Oil Sands Region, Alberta, Canada, Atmos. Environ., 60, 555-563, https://doi.org/10.1016/j.atmosenv.2012.06.046, 2012.

Ravishankara, A. R.: Heterogeneous and multiphase chemistry in the troposphere, Science, 276, 1058-1065, https://doi.org/10.1126/science.276.5315.1058, 1997.

Reche, C., Viana, M., Pandolfi, M., Alastuey, A., Moreno, T., Amato, F., Ripoll, A., and Querol, X.: Urban $\mathrm{NH}_{3}$ levels and sources in a Mediterranean environment, Atmos. Environ., 57, 153-164, 2012.

Reis, S., Pinder, R. W., Zhang, M., Lijie, G., and Sutton, M. A.: Reactive nitrogen in atmospheric emission inventories, Atmos. Chem. Phys., 9, 7657-7677, https://doi.org/10.5194/acp-9-76572009, 2009.

Richter, A., Burrows, J. P., Nuss, H., Granier, C., and Niemeier, U.: Increase in tropospheric nitrogen dioxide over China observed from space, Nature, 437, 129-132, 2005.

Sang, X. F., Gensch, I., Kammer, B., Khan, A., Kleist, E., Laumer, W., Schlag, P., Schmitt, S. H., Wildt, J., Zhao, R., Mungall, E. L., Abbatt, J. P. D., and Kiendler-Scharr, A.: Chemical stability of levoglucosan: an isotopic perspective, Geophys. Res. Lett., 43, 5419-5424, https://doi.org/10.1002/2016GL069179, 2016.

Savard, M. M., Cole, A. S., Vet, R., and Smirnoff, A.: The $\Delta^{17} \mathrm{O}$ and $\delta^{18} \mathrm{O}$ values of atmospheric nitrates simultaneously collected downwind of anthropogenic sources - implications for polluted air masses, Atmos. Chem. Phys., 18, 10373-10389, https://doi.org/10.5194/acp-18-10373-2018, 2018.

Schlesinger, W. and Hartley, A.: A global budget for atmospheric $\mathrm{NH}_{3}, \quad$ Biogeochem., 15, 191-211, https://doi.org/10.1007/BF00002936, 1992.
Schurman, M. I., Boris, A., Desyaterik, Y., and Collett, J. L.: Aqueous secondary organic aerosol formation in ambient cloud water photo-oxidations, Aerosol Air Qual. Res., 18, 15-25, https://doi.org/10.4209/aaqr.2017.01.0029, 2018.

Seinfeld, J. and Pandis, S. N.: Atmospheric Chemistry and Physics: From air pollution to climate change, John Wiley and Sons, 2012.

Seinfeld, J. H., Bretherton, C., Carslaw, K. S., Coe, H., DeMott, P. J., Dunlea, E. J., Feingold, G., Ghan, S., Guenther, A. B., Kahn, R., Kraucunas, I., Kreidenweis, S. M., Molina, M. J., Nenes, A., Penner, J. E., Prather, K. A., Ramanathan, V., Ramaswamy, V., Rasch, P. J., Ravishankara, A. R., Rosenfeld, D., Stephens, G., and Wood, R.: Improving our fundamental understanding of the role of aerosol-cloud interactions in the climate system, P. Natl. Acad. Sci. USA, 113, 5781-5790, https://doi.org/10.1073/pnas.1514043113, 2016.

Slade, J. H., Shiraiwa, M., Arangio, A., Su, H., Pöschl, U., Wang, J., and Knopf, D. A.: Cloud droplet activation through oxidation of organic aerosol influenced by temperature and particle phase state, Geophys. Res. Lett., 44, 1583-1591, https://doi.org/10.1002/2016GL072424, 2017.

Smirnoff, A., Savard, M. M., Vet, R., and Simard, M. C.: Nitrogen and triple oxygen isotopes in near-road air samples using chemical conversion and thermal decomposition, Rapid Commun. Mass Sp., 26, 2791-2804, https://doi.org/10.1002/rcm.6406, 2012.

Souri, A. H., Choi, Y., Jeon, W., Kochanski, A. K., Diao, L., Mandel, J., Bhave, P. V., and Pan, S.: Quantifying the impact of biomass burning emissions on major inorganic aerosols and their precursors in the U.S, J. Geophys. Res., 122, 12, https://doi.org/10.1002/2017JD026788, 2017.

Suarez-Bertoa, R., Zardini, A. A., and Astorga, C.: Ammonia exhaust emissions from spark ignition vehicles over the New European Driving Cycle, Atmos. Environ., 97, 43-53, 2014.

Teng, X., Hu, Q., Zhang, L., Qi, J., Shi, J., Xie, H., Gao, H., and Yao, X.: Identification of major sources of atmospheric $\mathrm{NH}_{3}$ in an urban environment in Northern China during wintertime, Environ. Sci. Technol., 51, 6839-6848, 2017.

Tu, Y., Fang, Y., Liu, D., and Pan, Y.: Modifications to the azide method for nitrate isotope analysis, Rapid Commun. Mass Sp., 30, 1213-1222, https://doi.org/10.1002/rcm.7551, 2016.

van Pinxteren, D., Fomba, K. W., Mertes, S., Müller, K., Spindler, G., Schneider, J., Lee, T., Collett, J. L., and Herrmann, H.: Cloud water composition during HCCT-2010: Scavenging efficiencies, solute concentrations, and droplet size dependence of inorganic ions and dissolved organic carbon, Atmos. Chem. Phys., 16, 3185-3205, https://doi.org/10.5194/acp-16-3185-2016, 2016.

Vega, C., Mårtensson, M., Wideqvist, U., Kaiser, J., Zieger, P., and StrÖm, J.: Composition, isotopic fingerprint and source attribution of nitrate deposition from rain and fog at a Sub-Arctic Mountain site in Central Sweden (Mt Åreskutan), Tellus B, 71, 1445379, https://doi.org/10.1080/16000889.2018.1559398, 2019.

Voigt, A. and Shaw, T. A.: Circulation response to warming shaped by radiative changes of clouds and water vapour, Nat. Geosci., 8 , 102-106, https://doi.org/10.1038/ngeo2345, 2015.

Walters, W. W. and Michalski, G.: Theoretical calculation of nitrogen isotope equilibrium exchange fractionation factors for various $\mathrm{NO}_{y}$ molecules, Geochim. Cosmochim. Ac., 164, 284-297, https://doi.org/10.1016/j.gca.2015.05.029, 2015. 
Walters, W. W., Simonini, D. S., and Michalski, G.: Nitrogen isotope exchange between $\mathrm{NO}$ and $\mathrm{NO}_{2}$ and its implications for $\delta^{15} \mathrm{~N}$ variations in tropospheric $\mathrm{NO}_{x}$ and atmospheric nitrate, Geophys. Res. Lett., 43, 440-448, https://doi.org/10.1002/2015gl066438, 2016.

Wang, Y. L., Liu, X. Y., Song, W., Yang, W., Han, B., Dou, X. Y., Zhao, X. D., Song, Z. L., Liu, C. Q., and Bai, Z. P.: Source appointment of nitrogen in $\mathrm{PM}_{2.5}$ based on bulk $\delta^{15} \mathrm{~N}$ signatures and a Bayesian isotope mixing model, Tellus B, 69, 1299672, https://doi.org/10.1080/16000889.2017.1299672, 2017a.

Wang, Z., Wang, W., Tham, Y. J., Li, Q., Wang, H., Wen, L., Wang, $X$., and Wang, T.: Fast heterogeneous $\mathrm{N}_{2} \mathrm{O}_{5}$ uptake and $\mathrm{ClNO}_{2}$ production in power plant and industrial plumes observed in the nocturnal residual layer over the North China Plain, Atmos. Chem. Phys., 17, 12361-12378, https://doi.org/10.5194/acp-1712361-2017, 2017b.

Weathers, K. C. and Likens, G. E.: Clouds in Southern Chile: An important source of nitrogen to nitrogenlimited ecosystems?, Environ. Sci. Technol., 31, 210-213, https://doi.org/10.1021/es9603416, 1997.

Yang, J.-Y. T., Hsu, S.-C., Dai, M. H., Hsiao, S. S.-Y., and Kao, S.-J.: Isotopic composition of water-soluble nitrate in bulk atmospheric deposition at Dongsha Island: sources and implications of external N supply to the northern South China Sea, Biogeosciences, 11, 1833-1846, https://doi.org/10.5194/bg-111833-2014, 2014.

Yeatman, S., Spokes, L., Dennis, P., and Jickells, T.: Comparisons of aerosol nitrogen isotopic composition at two polluted coastal sites, Atmos. Environ., 35, 1307-1320, https://doi.org/10.1016/S1352-2310(00)00408-8, 2001.

Yienger, J. J. and Levy, H.: Empirical model of global soil-biogenic $\mathrm{NO}_{x}$ emissions, J. Geophys. Res., 100, 11447-11464, 1995.

Zhang, C., Geng, X., Wang, H., Zhou, L., and Wang, B.: Emission factor for atmospheric ammonia from a typical municipal wastewater treatment plant in South China, Environ. Pollut., 220, 963-970, 2017.
Zhang, L., Chen, Y., Zhao, Y., Henze, D. K., Zhu, L., Song, Y., Paulot, F., Liu, X., Pan, Y., Lin, Y., and Huang, B.: Agricultural ammonia emissions in China: reconciling bottom-up and top-down estimates, Atmos. Chem. Phys., 18, 339-355, https://doi.org/10.5194/acp-18-339-2018, 2018.

Zhang, Y. L., and Cao, F.: Is it time to tackle $\mathrm{PM}_{2.5}$ air pollutions in China from biomass-burning emissions?, Environ. Pollut., 202, 217-219, https://doi.org/10.1016/j.envpol.2015.02.005, 2015.

Zhang, Y., Zheng, L. X., Liu, X. J., Jickells, T., Cape, J. N., Goulding, K., Fangmeier, A., and Zhang, F. S.: Evidence for organic $\mathrm{N}$ deposition and its anthropogenic sources in China, Atmos. Environ., 42, 1035-1041, https://doi.org/10.1016/j.atmosenv.2007.12.015, 2008.

Zhang, Y., Dore, A. J., Ma, L., Liu, X. J., Ma, W. Q., Cape, J. N., and Zhang, F. S.: Agricultural ammonia emissions inventory and spatial distribution in the North China Plain, Environ. Pollut., 158, 490-501, https://doi.org/10.1016/j.atmosenv.2007.12.015, 2010.

Zhao, Y., Zhang, J., and Nielsen, C. P.: The effects of recent control policies on trends in emissions of anthropogenic atmospheric pollutants and $\mathrm{CO}_{2}$ in China, Atmos. Chem. Phys., 13, 487-508, https://doi.org/10.5194/acp-13-487-2013, 2013.

Zheng, X. D., Liu, X. Y., Song, W., Sun, X. C., and Liu, C. Q.: Nitrogen isotope variations of ammonium across rain events: Implications for different scavenging between ammonia and particulate ammonium, Environ. Pollut., 239, 392-398, https://doi.org/10.1016/j.envpol.2018.04.015, 2018.

Zong, Z., Wang, X., Tian, C., Chen, Y., Fang, Y., Zhang, F., Li, C., Sun, J., Li, J., and Zhang, G.: First assessment of $\mathrm{NO}_{x}$ sources at a regional background site in North China using isotopic analysis linked with modeling, Environ. Sci. Technol., 51, 5923-5931, https://doi.org/10.1021/acs.est.6b06316, 2017. 